\section{OFFICE OF NAVAL RESEARCH LABORATORY OF OCEANO- GRAPHY AND HYDRAULICS LABORATORY, WOODS HOLE, MASSACHUSETTS}

\author{
By GORDON G. LILL
}

Geophysics Branch, Office of Naval Research, Washington 25, D.C.

$\mathrm{B}^{\mathrm{r}}$ June of this year the Bureau of Yards and Docks of the United States Navy will have completed the construction of a new Laboratory of Oceanography and Hydraulics Laboratory in the village of Woods Hole, Massachusetts. Work at the Laboratory will be conducted under the control and sponsorship of the Office of Naval Research, although it is expected that oceanographical research of a general character will be carried out at the new laboratory.

The reasons for locating the new laboratories in Woods Hole are simple but of significance when one thinks of the most profitable means of fostering research. Woods Hole is unique on the Atlentic coast as a scientific community devoted to occanic studies. The Marine Biological Laboratory, the Woods Hole Oceanographic Institution, and the U.S. Fish and Wildlife Service Laboratory, through the high quality of their research, have created a scientific atmosphere that will quickly stimulate the activities at a new laboratory and keep them alive. One of the world's most nearly complete oceanographical libraries has been collected jointly by this group and is located in the Marine Biological Laboratory, where it is used by all. Research vessels and dock facilities are available in addition to a complete and modern assemblage of oceanographical instruments. In the face of these qualifications, which are not duplicated elsewhere, Woods Hole could not be excelled as the site for the new laboratories.

The primary reason, of course, for constructing the laboratories is to assist in meeting the increasing requirement of the U.S. Navy for oceanographical information. However, justification of this sort cannot be divorced from others which are of more importance to the general scientific welfare. For example, the Woods Hole Oceanographic Institution has contracted with the Navy to perform marine research for many years. As a result of meeting the requirements of the Navy, the administration of the Institution has limited the use of its facilities by private scientists who desire on occasion to work there. A situation of this sort is obviously detrimental and should be at least partially alleviated by the new laboratories. The Marine Biological Laboratory also performs contract research for the Navy, and the Fish and Wildlife Service has long co-operated with the Navy on many research problems. It is likely that these two activities will find the new facilities to be of benefit as well. It is difficult to specify the research work at Woods Hole by agencies or laboratories. From the point of view of the Office of Naval

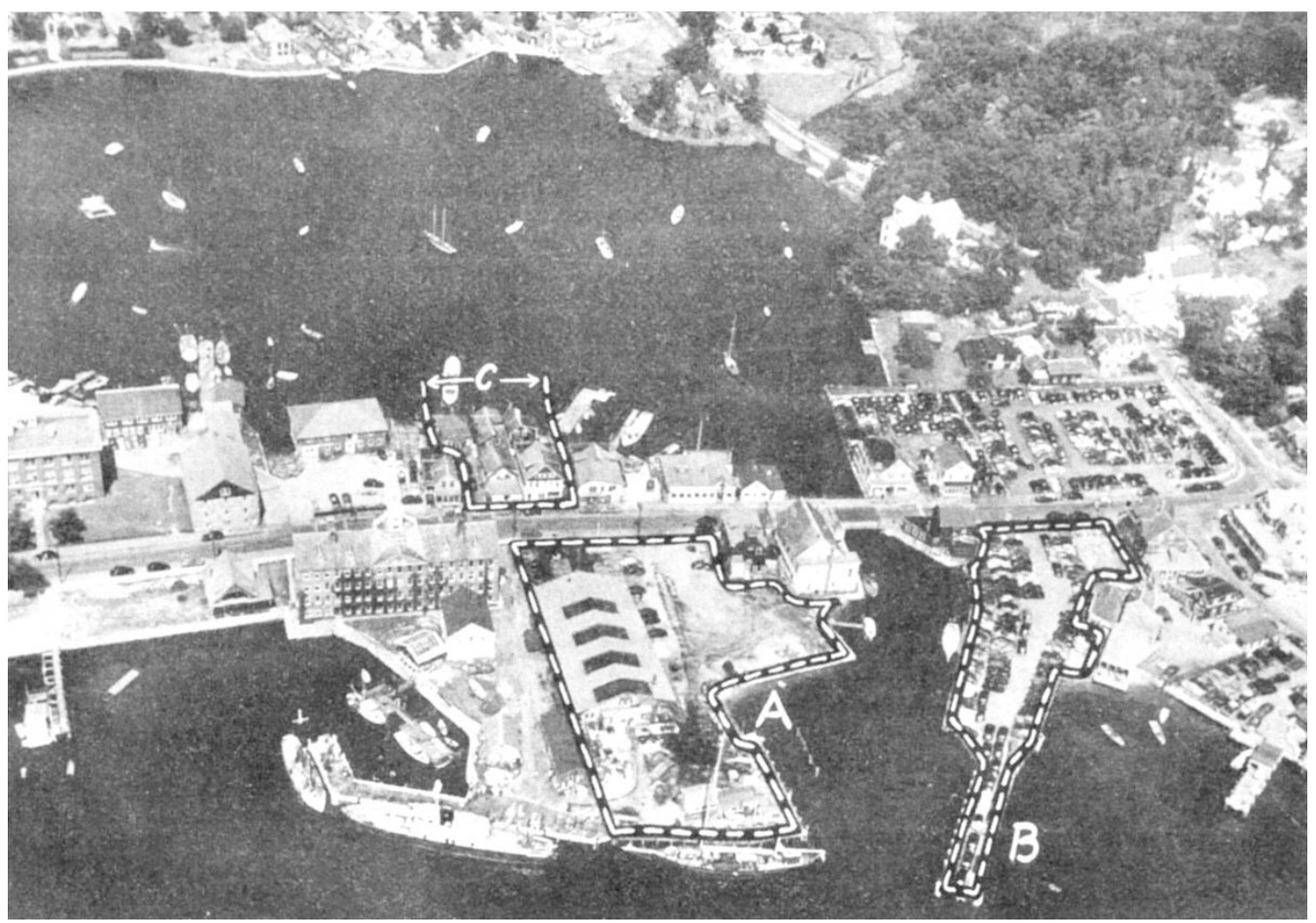

Fig. 1. Three sites, $A, B, C$, at Woods Hole, considered for the Laboratory of Oceanography ; site $A$ was chosen. The Marine Biological Laboratory is at the left; Woods Hole Oceanographical Institution is left centre; Eel Pond is in the background 


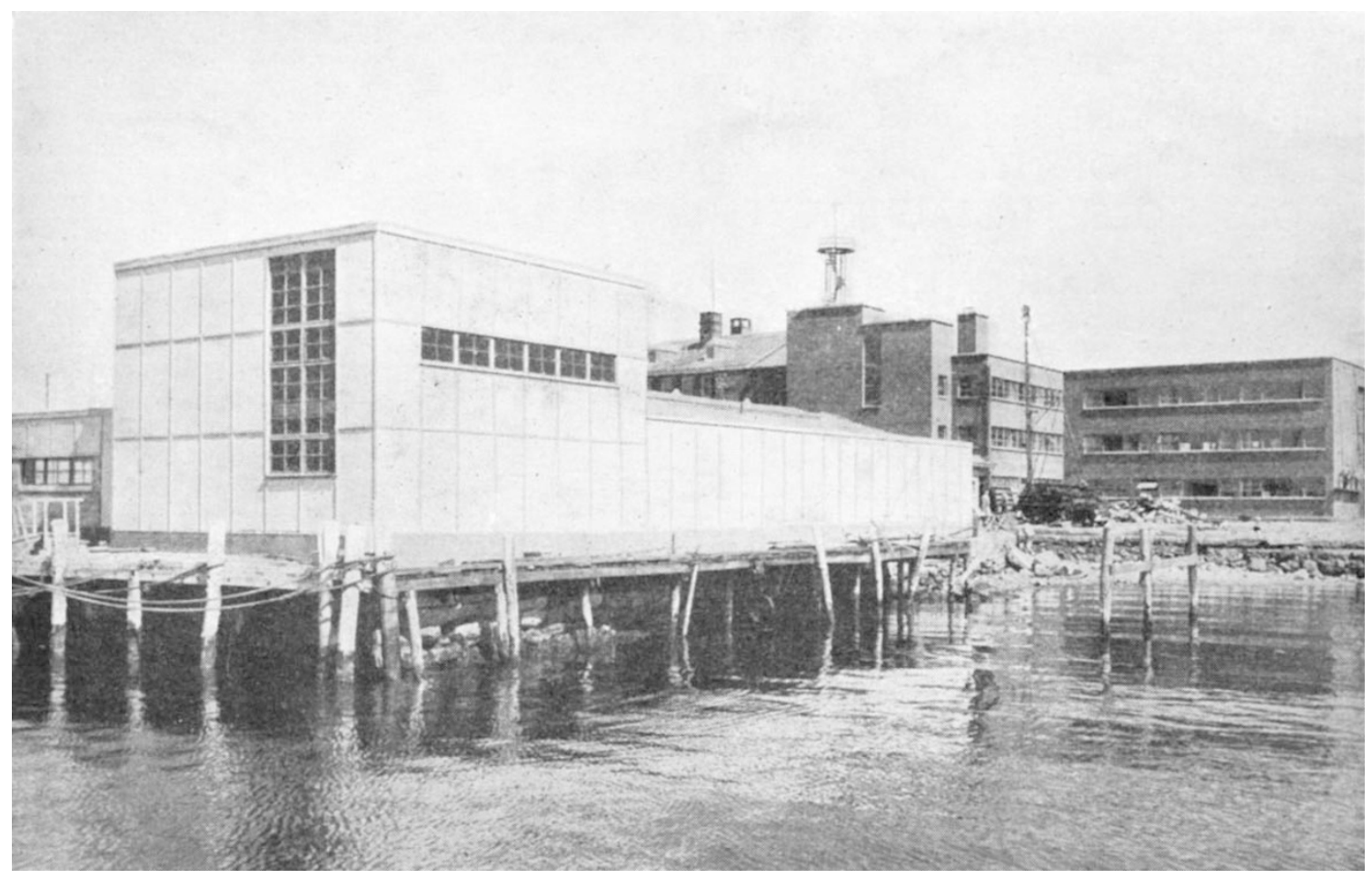

Fig. 2. Hydraulics Laboratory and, in the background, the main building of the Office of Naval Research Laboratory of Oceano-

Research the laboratories of the village must be considered as a scientific group, although at times through military necessity they may give the impression of partiality to one or another particular science. Here again we find a situation that can, and probably will, be eased.

In constructing the Laboratory of Oceanography advantage was taken of the machine shop already on the premises. The construction also includes an inexpensive, but adequate, Hydraulics Laboratory. Both buildings are mentioned in the following quotation taken from the Bureau of Yards and Docks Specifications:

"General Description. The unit at the front of the site shall be a three story structure in front and one story in the rear, the latter part being an existing building to be altered and extended. There will be no basement. Construction will be a concrete foundation with steel frame above, concrete slab floors and roof with exterior walls of brick and concrete blocks.

"The unit at the rear of the site (Hydraulics Laboratory) shall be a wood framed building with walls and roof of insulating board on concrete foundation."

On the first floor of the Laboratory of Oceanography and to the left of the entrance lobby are two large conference rooms, and beyond these are several private offices and an underwater acoustics laboratory, plus a small photographic dark-room. A corridor from the lobby to the rear of the building leads to the shop and to storage areas which will be devoted to instrument repair, instrument development, instrument storage, the machine shop, carpenter shop, stock room, laboratory services room, boiler and generator rooms, lavatories, and locker rooms. It should be noted that the underwater acoustics shop has been electrically insulated from the others by copper wire mesh completely surrounding the room.

Roughly one-half of the second floor is reserved for the instrument development section. The remainder will be utilized for drafting, multilithing, opaquing and photographic work. To the rear of the building, over the shop spaces, are located various storage rooms.

The third floor has been largely set aside for the hydrographic laboratory group. There are also a general research laboratory and a small room.

An instrument tower some 25-30 ft. in height is Iocated on the roof of the building. The tower will be equipped with meteorological instruments. The roof itself is flat and can be used for out-of-doors research when desired.

The spaces briefly described in the foregoing encompass about 28,000 sq. ft., which nearly duplicates the area of the Oceanographic Institution.

The smaller of the two buildings, the Hydraulics Laboratory, will contain a flume $100 \mathrm{ft}$. long by $4 \mathrm{ft}$. deep by $4 \mathrm{ft}$. wide. To one side of the flume will be a circular tank $2 \mathrm{ft}$. deep by $20 \mathrm{ft}$. in diameter. This building also has a small balcony office and a shop for welding and other metal-work.

A few characteristics of the Laboratory of Oceanography which are of particular interest may be mentioned. The building is completely water-and fireproof. The floors are constructed of preformed, prestressed concrete blocks which, where covered with asphalt tile, will have a 'dusted off' finish and where exposed will be given $a^{\prime}$ 'hardening treatment with a water solution of magnesium-fluosilicate erystals. In the laboratories and corridors the ceilings will be covered by acoustic tiling. Movable 
partitions of pressed or rolled steel will be installed throughout. Electrical, gas, fresh- and salt-water, and compressed-air outlets are fixed at regular intervals, so that if partitions are rearranged these facilities will always be accessible. A hydraulic lift, operated by oil, and $6 \mathrm{ft}$. by $9 \mathrm{ft}$. in dimensions with a net lifting capacity of $\mathbf{5 , 0 0 0} \mathbf{l b}$., will be centrally installed. The laboratories and shops will be fitted with 115 volt d.c. and 440 volt a.c. 3-phase electrical outlets. An engine-generator for emergency lighting and oil-burning equipment will be installed in the generating room.

The construction of the two buildings is being carried out by the C. Sullivan Company, Inc., of Newport, Rhode Island, under contract with the Bureau of Yards and Docks. The architect was Mr. Gunnar Peterson, of Falmouth, Massachusetts. The resident officer in charge of construction is Lieutenant Robert P. Lathrop (C.E.C.), U.S.N.R.

The building will be ready for occupation by about June 1. A dedication ceremony is planned by the Navy for June 21, to be followed by a three-day oceanographical convocation on many of the important phases of the marine sciences. Scientists from Britain, Denmark, The Netherlands, Norway, Sweden and the United States will participate in the proceedings of the convocation, which will be sponsored co-operatively by the scientific community at Woods Hole, the National Research Council of the National Academy of Sciences, and the Office of Naval Research. The papers presented at the meeting will be published in one volume by the National Academy.

The research accomplishments of the scientists at Woods Hole have resulted in world-wide fame for the village. The Office of Naval Research anticipates with pleasure the opportunity of assisting in the scientific effort of the community.

\section{A LINK BETWEEN 'MODELS' AND LIVING MUSCLE \\ By DR. ARPAD CSAPO \\ Department of Embryology, Carnegie Institution of Washington, Baltimore, Md.}

$\mathrm{I}^{\mathrm{T}}$

is concluded from experiments on muscle 'models' that the final reaction of muscular contraction is an interreaction between actomyosin and adenosine triphosphate in the presence of ions ${ }^{1,8}$. If the delicate architecture of the actomyosin particles is preserved, as in glycerol-treated psoas muscle, the model develops about the same tension as it does in the living condition. This model can also relax after an isometric contraction if creatin phosphate and 'adenosine triphosphatecreatine transphosphorylase', which are removed by glycerol treatment, are replaced ${ }^{3,4}$. When activated by adenosine triphos. phate, it shows the well-known changes in the elastic modulus, characteristic of active living muscle (ref. 2, quoted in ref. 1).

A well-recognized difference exists, however, between the behaviour of the models and that of living muscle. The former develop maximum tension in isotonic potassium chloride, whereas living muscle becomes 'inexcitable' in this condition, developing practically no tension upon the application of an otherwise optimum stimulus. Inexcitability is explained by the disappearance of the electrochemical gradients ${ }^{5}$.

It is of interest to know whether in living muscle, in the absence of these gradients, the final contractile system retains its maximum capacity for the development of tension. Experiments to be reported here indicate that maximum tension can be repeatedly obtained in living muscle in the absence of both potassium and sodium gradients, and thus the processes of activation and isometric contraction can be separated experimentally. Such maximum activation of an 'inexcitable' living muscle, in the absence of the gradients, can be produced by an electrical stimulus (essentially a longitudinal field produced in the perfusion bath between two platinum ring electrodes) five times stronger than required for maximum tension when the gradients are present. This stimulus does not lead to irreversible changes in the living muscle.

Estrogen-dominated ${ }^{6}$ rabbit uteri were used. In previous experiments this tissue was found to maintain its high-energy phosphate stores in vitro (in the presence of $100 \mathrm{mgm}$. per cent glucose) for several hours. It also maintained the capacity to develop maximum tension for a period of seven days if it was stored between tests at $+4^{\circ} \mathrm{C}$. in a mammalian Krebs's solution in which five-sixths of the sodium chloride was replaced by isotonic glucose. One can assume, therefore, that within the two hours duration of the present experiments the contractile system was unaltered. The fact that the myometrium has been used in these experiments does not imply that other muscles do not have the same or similar properties.

Segments of the tubular uterine horm about $40 \mathrm{~mm}$. long (at resting length), about $5 \mathrm{~mm}$. in outside diameter, and with muscle walls about $1 \mathrm{~mm}$. thick, were mounted on platinum hooks, in a 13-ml. bath of mammalian Krebs's solution, between two platinum ring electrodes. The rings were $12 \mathrm{~mm}$. in diameter, $65 \mathrm{~mm}$. apart. Temperature was kept constant at $37 \cdot 5^{\circ} \mathrm{C}$. and the $p \mathrm{H}$ at 7.4 by oxygenating the Krebs's solution with 95 per cent oxygen +5 per cent carbon dioxide (for material and techniques see ref. 6). For electrical stimulation alternating current (60 cycles) rather than direct current was used, for reasons discussed elsewhere ${ }^{7}$. The duration of the a.c. stimulus and the time-interval between two subsequent stimuli were kept constant at the optima. ( 5 sec. and 1 min., respectively) and only the field-

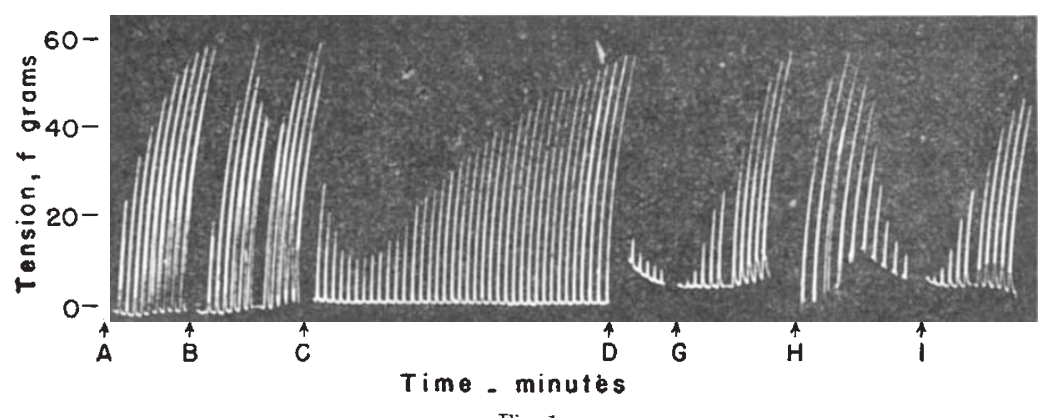

F'ig. 1 